\title{
A Facile Route to Phosphanylborohydrides: Synthesis, Crystal Structure and Spectroscopic Properties of 1,2-Bis(Diphenylphosphinoborane)Ethane
}

\author{
Leyla Tatar Yildirim ${ }^{1}$, Mehdi Masjedi ${ }^{2}$, Saim Özkar² \\ ${ }^{1}$ Department of Engineering Physics, Hacettepe University, Ankara, Turkey; \\ ${ }^{2}$ Department of Chemistry, Middle East Technical University, Ankara, Turkey \\ E-mail: ${ }^{1}$ tatar@hacettepe.edu.tr, ${ }^{2}$ mehdimasjedi@yahoo.com, ${ }^{3}$ sozkar@metu.edu.tr
}

Received February $22^{\text {nd }}, 2011$; revised March $16^{\text {th }}, 2011$; accepted March $17^{\text {th }}, 2011$.

\begin{abstract}
A novel and simple synthetic way using $\mathrm{NaBH}_{4}$ in the mixture of $\mathrm{H}_{2} \mathrm{O}$-THF was applied to prepare 1,2-bis(diphenylphosphinoborane)ethane, dppe $\left(\mathrm{BH}_{3}\right)_{2}$, in high yield and purity. The phosphanylborohydride compound $\mathrm{dppe}_{(\mathrm{BH}} \mathrm{B}_{2}$ was isolated in the form of colorless crystals and characterized by single crystal $\mathrm{X}$-ray diffraction, ${ }^{1} \mathrm{H},{ }^{13} \mathrm{C},{ }^{31} \mathrm{P}$ and ${ }^{11} \mathrm{~B} N \mathrm{NMR}$ spectroscopy. Prismatic colorless crystals of dppe $\left(\mathrm{BH}_{3}\right)_{2}$ were obtained in monoclinic crystal system and space group $P 2_{1}$ with two asymmetric units in the unit cell. Lattice parameters were: $a=11.657(2), b=17.237(2), c=12.764(2) \AA$, $\beta=98.735(14)^{\circ}, 2535.0(7) \AA^{3}$.
\end{abstract}

Keywords: Crystal Structure, Synthesis, Phosphinoborane, Sodium Borohydride, Phosphanylborohydride, $X$-Ray Diffraction

\section{Introduction}

A recent study [1] has reported the catalytic activity of ruthenium (III) acetylacetonate in the presence of different phosphorus compounds such as 1,2-bis(diphenylphosphino)ethane, dppe, in the hydrolysis of sodium borohydride. At the end of catalytic reaction, in addition to the unreacted dppe, unexpectedly we isolated a new species which contains two $\mathrm{BH}_{3}$ molecules coordinated to dppe. Obviously, in this catalytic reaction, $\mathrm{NaBH}_{4}$ acts not only as a substrate to generate hydrogen, but also as a $\mathrm{BH}_{3}$ supplier in forming phosphanylborohydrides such as 1,2-bis(diphenylphosphinoborane)ethane, dppe $\left(\mathrm{BH}_{3}\right)_{2}$. In literature, phosphanylborohydrides have been prepared by using the mixture of sodium borohydride and iodine in monoglyme [2] or using the other borane sources: dppe $\left(\mathrm{BH}_{3}\right)_{2}$ by complexation of dppe with $\mathrm{BH}_{3} \cdot \mathrm{S}\left(\mathrm{CH}_{3}\right)_{2}$ [3], rac/meso- $\left[\mathrm{HP}\left(\mathrm{BH}_{3}\right)(\mathrm{Ph}) \mathrm{CH}_{2}\right]_{2}$ from the reaction of $\mathrm{BH}_{3}$.thf [4] or reaction of phosphine oxides with diborane [5], from the reaction of trialkylphosphines with bromoboranes or bromochloroboranes [6]. In addition following phosphanylborohydrides have been reported: tertiary mono and diphosphine-borane complexes [7-9], cyclic phosphine-boranes [10], phosphine-carborane clusters [11], phosphinyl-borane radicals [12] and phosphine alkylene boranes [13]. It is noteworthy that the phosphanylborohydride $\left[\mathrm{P}\left(\mathrm{BH}_{3}\right) \mathrm{Ph}_{2}\right]^{-}$forms dative bonds of higher $\mathrm{p}$ character and establish more stable $\sigma$ adducts towards the acceptor orbital of the Lewis acid in comparison with its neutral counterpart $\mathrm{P}\left(\mathrm{CH}_{3}\right) \mathrm{Ph}_{2}$ [14]. A similar phenomenon was observed in the study of chalcogenated phosphanylborohydrides $\mathrm{K}\left[\mathrm{EP}\left(\mathrm{BH}_{3}\right) \mathrm{R}_{2}\right](\mathrm{E}: \mathrm{O}$, $\mathrm{S}, \mathrm{Se}, \mathrm{Te} ; \mathrm{R}: \mathrm{Ph}, t-\mathrm{Bu})$ with a certain degree of $\mathrm{E}=\mathrm{P}$ multiple bond character [15]. Borane complexes of phosphorus compounds, a very common oxidation free relay for catalytic ligands (phosphines, phosphites or phosphinites) can be easily deprotected by treatment with polymer- supported piperazine, N-methylpiperazine [16] or pyrrol derivatives [3]. Phosphanylborohydrides supported by amines such as polypyrroles, are very useful for homogeneous catalysis due to more efficient recovery and purification [3]. Despite the known examples given above, the chemistry of phosphanylborohydrides is still largely undeveloped [17-22]. Herein we report a new and simple synthetic way using $\mathrm{NaBH}_{4}$ in an homogeneous aqueous-organic

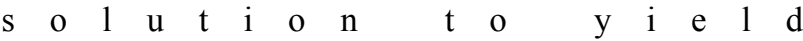


1,2-bis(diphenylphosphinoborane)ethane, dppe $\left(\mathrm{BH}_{3}\right)_{2}$, and its characterization by single crystal X-ray diffraction, ${ }^{1} \mathrm{H},{ }^{13} \mathrm{C},{ }^{31} \mathrm{P}$ and ${ }^{11} \mathrm{~B}$ NMR spectroscopy.

\section{Experimental}

\subsection{Materials}

Sodium borohydride, $\mathrm{NaBH}_{4}(98 \%)$ and 1,2-bis(diphenylphosphino)ethane, dppe, were purchased from Aldrich. Tetrahydrofuran, THF and dichloromethane, $\mathrm{CH}_{2} \mathrm{Cl}_{2}$ were purchased from Merck. All glassware and Teflon-coated magnetic stir bars were cleaned with acetone, followed by copious rinsing with distilled water before drying at $150^{\circ} \mathrm{C}$ in oven for a few hours.

\subsection{Equipment}

All reactions involving air sensitive compounds were performed under argon or nitrogen atmospheres. ${ }^{1} \mathrm{H},{ }^{13} \mathrm{C}$, ${ }^{31} \mathrm{P}$ and ${ }^{11} \mathrm{~B}$ NMR spectra were recorded on Bruker Avance DPX $400 \mathrm{MHz}$ spectrometer $\left(400.1 \mathrm{MHz}\right.$ for ${ }^{1} \mathrm{H}$; 100.6 MHz for ${ }^{13} \mathrm{C}$; $161.3 \mathrm{MHz}$ for ${ }^{31} \mathrm{P}$; $128.2 \mathrm{MHz}$ for $\left.{ }^{11} \mathrm{~B}\right)$. TMS was used as internal reference for ${ }^{1} \mathrm{H}$ and ${ }^{13} \mathrm{C}$ NMR chemical shifts. $\mathrm{BF}_{3} \cdot\left(\mathrm{C}_{2} \mathrm{H}_{5}\right)_{2} \mathrm{O}$ was used as external reference for ${ }^{11} \mathrm{~B}$ NMR chemical shifts. $\mathrm{H}_{3} \mathrm{PO}_{4}(85 \%$ in glass capillary) was used as reference for ${ }^{31} \mathrm{P}$ NMR. Positive ion mass spectrometry data was obtained on a Bruker Micro TOF-LC/ESI/Ms system.

The experimental setup consists of a $75 \mathrm{~mL}$ jacketed reaction flask containing a Teflon-coated stir bar placed on a magnetic stirrer (Heidolph MR-301) which can be thermostated to $25.0^{\circ} \mathrm{C}$ by circulating water through its jacket from a constant temperature bath (RL6 LAUDA water bath). Note that hydrogen liberated during hydrolysis of sodium borohydride was released from the flask through a bubbler.

\subsection{Synthesis of 1,2-Bis(Diphenylphosphinobo- rane)Ethane, $\mathrm{DPPE}\left(\mathrm{BH}_{3}\right)_{2}$}

For the preparation of 1,2-bis(diphenylphosphinoborane) ethane, dppe $\left(\mathrm{BH}_{3}\right)_{2}, 140 \mathrm{mg}(0.35 \mathrm{mmol})$ of 1,2-bis(diphenylphospino)ethane, dppe, was dissolved in $10 \mathrm{~mL}$ of THF by vigorous stirring. Then, the solution was transferred into a $75 \mathrm{~mL}$ jacketed reaction flask containing 30 $\mathrm{mg}(0.79 \mathrm{mmol}) \mathrm{NaBH}_{4}$ dissolved in $40 \mathrm{~mL}$ water and thermostated at $25.0^{\circ} \mathrm{C}$. The reaction was started by turning on the magnetic stirrer (Heidolph MR-301) at $1000 \mathrm{rpm}$ under inert atmosphere (argon or nitrogen). After $3 \mathrm{~h}$ stirring, the mixture was extracted with dichloromethane and the combined organic extracts were cooled in order to precipitate out traces of sodium borohydride or metaborate remaining in organic extracts.
Then, the solution was dried over magnesium sulfate, filtered and evaporated in vacuum giving $144 \mathrm{mg}$ of pure dppe $\left(\mathrm{BH}_{3}\right)_{2}$ complex (96\% yield). Colorless crystals of dppe $\left(\mathrm{BH}_{3}\right)_{2}$ were obtained by crystallization from the hexane-dichloromethane solution at $0^{\circ} \mathrm{C}$ after one week, which were separated by filtration. $\left[\mathrm{Ph}_{2} \mathrm{P}\left(\mathrm{BH}_{3}\right) \mathrm{CH}_{2}\right]_{2}:{ }^{1} \mathrm{H}$ NMR $\left(\mathrm{CD}_{2} \mathrm{Cl}_{2}, \mathrm{ppm}\right): \delta 1.99$ (t, 6H, $\left.\mathrm{J}_{\mathrm{P}-\mathrm{H}}=4.8 \mathrm{~Hz}, 2 \mathrm{BH}_{3}\right)$, 2.15 (br d, $2 \mathrm{H}, \mathrm{J}_{\mathrm{P}-\mathrm{H}}=6.4 \mathrm{~Hz}, \mathrm{CH}_{2}$ ), 2.38 (br d, $\mathrm{J}_{\mathrm{P}-\mathrm{H}}=2.8$ $\left.\mathrm{Hz}, 2 \mathrm{H}, \mathrm{CH}_{2}\right), 7.38$ (m, 12H, H-m,p), 7.54(m, 4H, H-o), $7.61(\mathrm{~m}, 4 \mathrm{H}, \mathrm{H}-\mathrm{o}) .{ }^{13} \mathrm{C}\left\{{ }^{1} \mathrm{H}\right\}$ NMR $\left(\mathrm{CD}_{2} \mathrm{Cl}_{2}, \mathrm{ppm}\right): \delta$ 22.93, 127.81, 129.87, 131.85, 137.59. ${ }^{31} \mathrm{P}\left\{{ }^{1} \mathrm{H}\right\}$ NMR $\left(\mathrm{CD}_{2} \mathrm{Cl}_{2}, \mathrm{ppm}\right): \delta-12.5 .{ }^{11} \mathrm{~B}\left\{{ }^{1} \mathrm{H}\right\}$ NMR $\left(\mathrm{CD}_{2} \mathrm{Cl}_{2}, \mathrm{ppm}\right)$ : $\delta-40.06$.

\section{Crystal Structure Analysis}

$\mathrm{X}$-ray diffraction measurements were performed with $\mathrm{MoK}_{\alpha}$ radiation on an Enraf-Nonius CAD4 diffractometer [23] equipped with a graphite monochromator. Intensity data were collected by $\omega / 2 \theta$ scan mode. The cell parameters were determined from a least-squares refinement of 18 centered reflections in the range of $10.12^{\circ} \leq \theta$ $\leq 18.03^{\circ}$. Cell refinement was carried out using CAD-4 EXPRESS. Data reduction was carried out using XCAD4 [24]. The structures were solved by Patterson methods and refined using the program SHELX [25]. A full-matrix least-squares refinement on $F^{2}$ was done. For all non-hydrogen atoms anisotropic displacement parameters were refined. Borane $\left(\mathrm{BH}_{3}\right)$ and phenyl ring hydrogen's of the compound were placed geometrically and a riding model was used with $U_{\text {iso }}(H)=1.5 U_{e q}(C)$ and $U_{\text {iso }}(H)=1.2 U_{e q}(C)$, respectively. Methylene hydrogen's were taken from a difference Fourier map and refined. Single crystal X-ray diffraction analysis of the colorless crystal shows the crystallization in monoclinic system with space group $P 2_{1}$ and two asymmetric units with a formula of $\mathrm{C}_{26} \mathrm{H}_{30} \mathrm{~B}_{2} \mathrm{P}_{2}$ and four molecules per unit cell. Table 1 shows the crystal data and crystal refinement of dppe $\left(\mathrm{BH}_{3}\right)_{2}$. The atomic coordinates and isotropic displacement parameters are listed in Table 2. Selected bond lengths and angles are given in Table 3. ORTEP [26] drawing of the dppe $\left(\mathrm{BH}_{3}\right)_{2}$ complex with the atomic numbering scheme is given in Figure 1. The unit cell of the structure as shown in Figure 2. The conformations of molecules and molecular packing geometry were analyzed using PLATON [27]. The structure includes several pi-ring interactions between two asymmetric moieties. Details of the pi-ring interaction geometry are given in Table 4.

\section{Results and Discussion}

When an aqueous solution of sodium borohydride is added to a solution of 1,2-bis(diphenylphospino)ethane, 
Properties of 1,2-Bis(Diphenylphosphinoborane)Ethane

dppe, in tetrahydrofurane under vigorous stirring in inert atmosphere at $25.0^{\circ} \mathrm{C}$, a reaction occurs, along with the

Table 1. Crystal data and structure refinement for dppe $\left(\mathrm{BH}_{3}\right)_{2}$.

\begin{tabular}{|c|c|}
\hline Chemical Formula & $\mathrm{C}_{26} \mathrm{H}_{30} \mathrm{~B}_{2} \mathrm{P}_{2}$ \\
\hline Formula weight $[\mathrm{g} / \mathrm{mol}]$ & 426.06 \\
\hline Crystal colour and shape & prism, colorless \\
\hline Crystal size (mm) & $0.3 \times 0.3 \times 0.3$ \\
\hline Temperature (K) & $295(2)$ \\
\hline Crystal system, Space group & monoclinic, $\mathrm{P} 2{ }_{1}$ \\
\hline a $(\AA)$ & $11.657(2)$ \\
\hline b $(\AA)$ & $17.237(2)$ \\
\hline c $(\AA)$ & $12.764(2)$ \\
\hline$\beta\left(^{\circ}\right)$ & 98.735(14) \\
\hline Cell volume $\left(\AA^{3}\right)$ & $2535.0(7)$ \\
\hline $\mathrm{Z}$, calculated density $\left(\mathrm{g} / \mathrm{cm}^{3}\right)$ & $4,1.116$ \\
\hline Absorption coefficient $\left(\mathrm{mm}^{-1}\right)$ & 0.182 \\
\hline$F(000)$ & 904 \\
\hline$\theta$-range for data collection $\left({ }^{\circ}\right)$ & $2.21-26.29$ \\
\hline Limiting indices & $-14 \leq \mathrm{h} \leq 0,0 \leq \mathrm{k} \leq 21,-15 \leq 1 \leq 15$ \\
\hline Reflections collected / Unique & $5542 / 5286\left[\mathrm{R}_{\mathrm{int}}=0.0492\right]$ \\
\hline Data/restrains/parameters & $5286 / 553 / 4$ \\
\hline Goodness-of-fit on $F^{2}$ & 1.001 \\
\hline Final $R$ indices $[\mathrm{I}>2 \sigma(\mathrm{I})]$ & $R_{1}=0.0558, w R_{2}=0.1301$ \\
\hline Largest diff. peak and hole $\left(\mathrm{e} / \AA^{3}\right)$ & 0.519 and -0.303 \\
\hline
\end{tabular}

Further details on the structural investigation are available on request from the Cambridge Crystallographica Data Centre, quoting the depository number CCDC 752883.

Table 2. Atomic coordinates and equivalent isotropic displacement parameters $\left(\AA^{2}\right)$ for $\operatorname{dppe}\left(\mathrm{BH}_{3}\right)$.

\begin{tabular}{|c|c|c|c|c|c|c|c|c|c|}
\hline Atom & $\mathrm{x}$ & $\mathrm{y}$ & $\mathrm{z}$ & $\mathrm{U}_{\mathrm{eq}}$ & Atom & $\mathrm{x}$ & $\mathrm{y}$ & $\mathrm{z}$ & $\mathrm{U}_{\mathrm{eq}}$ \\
\hline \multicolumn{5}{|c|}{ Molecule I } & \multicolumn{5}{|c|}{ Molecule II } \\
\hline B1 & $0.4854(7)$ & $0.1328(6)$ & $0.9091(8)$ & $0.076(3)$ & B1' & $0.1375(10)$ & $0.3864(7)$ & $0.4564(7)$ & $0.098(4)$ \\
\hline B2 & $0.8379(9)$ & $0.1832(6)$ & $1.2510(7)$ & $0.085(3)$ & B2' & $0.6106(9)$ & $0.4078(8)$ & $0.7863(8)$ & $0.102(4)$ \\
\hline P1 & $0.62838(14)$ & $0.08831(10)$ & $0.89049(14)$ & $0.0544(5)$ & P1' & $0.19495(15)$ & $0.34115(11)$ & $0.58949(14)$ & $0.0597(5)$ \\
\hline P2 & $0.86384(15)$ & $0.22715(10)$ & $1.12275(14)$ & $0.0534(5)$ & P2' & $0.54049(16)$ & $0.45444(12)$ & $0.65608(15)$ & $0.0629(5)$ \\
\hline C1 & $0.6261(6)$ & $-0.0166(4)$ & $0.8938(5)$ & $0.0554(19)$ & C1' & $0.1708(6)$ & $0.2379(4)$ & $0.5901(5)$ & $0.0593(18)$ \\
\hline $\mathrm{C} 2$ & $0.6967(6)$ & $-0.0625(5)$ & $0.8385(6)$ & $0.071(2)$ & C2' & $0.2342(7)$ & $0.1881(5)$ & $0.6624(6)$ & $0.071(2)$ \\
\hline C3 & $0.6936(8)$ & $-0.1412(5)$ & $0.8464(7)$ & $0.089(3)$ & $\mathrm{C}^{\prime}$ & $0.2160(7)$ & $0.1088(5)$ & $0.6572(7)$ & $0.081(2)$ \\
\hline C4 & $0.6239(8)$ & $-0.1750(5)$ & $0.9098(7)$ & $0.084(3)$ & C4' & $0.1320(7)$ & $0.0775(5)$ & $0.5804(7)$ & $0.084(2)$ \\
\hline C5 & $0.5550(7)$ & $-0.1319(6)$ & $0.9644(7)$ & $0.083(2)$ & C5' & $0.0685(7)$ & $0.1260(5)$ & $0.5095(7)$ & $0.081(2)$ \\
\hline C6 & $0.5572(6)$ & $-0.0527(5)$ & $0.9566(6)$ & $0.073(2)$ & $\mathbf{C 6}^{\prime}$ & $0.0858(6)$ & $0.2057(5)$ & $0.5135(6)$ & $0.071(2)$ \\
\hline C7 & $0.6817(6)$ & $0.1161(4)$ & $0.7718(6)$ & $0.0621(19)$ & C7' & $0.1323(6)$ & $0.3814(4)$ & $0.6979(6)$ & $0.0596(18)$ \\
\hline C8 & $0.6033(8)$ & $0.1336(5)$ & $0.6817(7)$ & $0.092(3)$ & C8' & $0.0241(7)$ & $0.4146(6)$ & $0.6764(8)$ & $0.103(3)$ \\
\hline C9 & $0.6447(15)$ & $0.1521(7)$ & $0.5869(9)$ & $0.131(4)$ & C9' & $-0.0286(9)$ & $0.4421(7)$ & $0.7604(12)$ & $0.127(4)$ \\
\hline C10 & $0.7593(17)$ & $0.1524(8)$ & $0.5842(11)$ & $0.137(5)$ & C10' & $0.0270(12)$ & $0.4403(7)$ & $0.8622(11)$ & $0.122(4)$ \\
\hline C11 & $0.8375(11)$ & $0.1368(7)$ & $0.6693(10)$ & $0.126(4)$ & C11' & $0.1327(11)$ & $0.4088(6)$ & $0.8823(8)$ & $0.103(3)$ \\
\hline C12 & $0.7993(7)$ & $0.1182(5)$ & $0.7641(7)$ & $0.087(2)$ & C12' & $0.1867(7)$ & $0.3789(5)$ & $0.8012(6)$ & $0.083(2)$ \\
\hline C13 & $0.7410(6)$ & $0.1148(4)$ & $1.0009(6)$ & $0.0588(19)$ & C13' & $0.3526(6)$ & $0.3535(5)$ & $0.6246(8)$ & $0.071(2)$ \\
\hline C14 & $0.7504(7)$ & $0.2023(4)$ & $1.0154(7)$ & $0.062(2)$ & C14' & $0.3843(6)$ & $0.4399(5)$ & $0.6297(8)$ & $0.074(2)$ \\
\hline C15 & $0.9964(8)$ & $0.1979(6)$ & $1.0806(10)$ & $0.1055(16)$ & C15' & $0.5950(6)$ & $0.4217(4)$ & $0.5387(5)$ & $0.0599(18)$ \\
\hline C16 & $1.0228(8)$ & $0.2233(6)$ & $0.9836(9)$ & $0.1055(16)$ & C16' & $0.5452(7)$ & $0.4447(5)$ & $0.4389(6)$ & $0.081(2)$ \\
\hline C17 & $1.1287(8)$ & $0.2001(5)$ & $0.9498(9)$ & $0.1055(16)$ & C17' & $0.5935(9)$ & $0.4216(6)$ & $0.3511(7)$ & $0.094(3)$ \\
\hline C18 & $1.2024(8)$ & $0.1564(6)$ & $1.0190(9)$ & $0.1055(16)$ & C18' & $0.6882(9)$ & $0.3766(6)$ & $0.3618(8)$ & $0.094(3)$ \\
\hline C19 & $1.1808(8)$ & $0.1314(5)$ & $1.1106(9)$ & $0.1055(16)$ & C19' & $0.7410(8)$ & $0.3524(6)$ & $0.4595(8)$ & $0.093(3)$ \\
\hline $\mathrm{C} 20$ & $1.0748(7)$ & $0.1514(5)$ & $1.1433(8)$ & $0.097(3)$ & $\mathrm{C}^{\prime} \mathrm{O}^{\prime}$ & $0.6922(7)$ & $0.3747(5)$ & $0.5480(7)$ & $0.081(2)$ \\
\hline $\mathrm{C} 21$ & $0.8710(5)$ & $0.3316(4)$ & $1.1266(5)$ & $0.0498(17)$ & C21' & $0.5562(6)$ & $0.5580(4)$ & $0.6561(5)$ & $0.062(2)$ \\
\hline C22 & $0.7938(7)$ & $0.3779(5)$ & $1.0625(6)$ & $0.069(2)$ & C22' & $0.4858(7)$ & $0.6070(5)$ & $0.7037(7)$ & $0.089(3)$ \\
\hline C23 & $0.8033(7)$ & $0.4581(5)$ & $1.0697(7)$ & $0.084(2)$ & C23' & $0.5003(9)$ & $0.6864(6)$ & $0.7041(8)$ & $0.107(3)$ \\
\hline $\mathrm{C} 24$ & $0.8903(8)$ & $0.4909(5)$ & $1.1428(7)$ & $0.080(2)$ & C24' & $0.5826(10)$ & $0.7187(6)$ & $0.6564(8)$ & $0.100(3)$ \\
\hline
\end{tabular}




\begin{tabular}{llllllllll}
\hline C25 & $0.9654(7)$ & $0.4449(5)$ & $1.2062(6)$ & $0.081(2)$ & C25'$^{\prime}$ & $0.6512(10)$ & $0.6726(7)$ & $0.6109(9)$ & $0.118(4)$ \\
C26 & $0.9546(6)$ & $0.3663(4)$ & $1.1979(6)$ & $0.069(2)$ & C26' $^{\prime}$ & $0.6405(8)$ & $0.5929(5)$ & $0.6082(7)$ & $0.092(3)$ \\
\hline
\end{tabular}

Table 3. Selected bond length $[\AA]$ and angles $\left[^{\circ}\right]$ for two asymmetric units of dppe $\left(\mathrm{BH}_{3}\right)_{2}$.

\begin{tabular}{|c|c|c|c|}
\hline \multicolumn{2}{|c|}{ Molecule I } & \multicolumn{2}{|c|}{ Molecule II } \\
\hline $\mathrm{B} 1-\mathrm{P} 1$ & $1.882(8)$ & $\mathrm{B} 1^{\prime}-\mathrm{P} 1^{\prime}$ & $1.896(9)$ \\
\hline $\mathrm{B} 2-\mathrm{P} 2$ & $1.870(9)$ & $\mathrm{B} 2^{\prime}-\mathrm{P} 2^{\prime}$ & $1.914(10)$ \\
\hline $\mathrm{P} 1-\mathrm{C} 1$ & $1.809(7)$ & $\mathrm{P} 1^{\prime}-\mathrm{C} 1^{\prime}$ & $1.802(8)$ \\
\hline $\mathrm{P} 1-\mathrm{C} 7$ & $1.788(7)$ & $\mathrm{P} 1^{\prime}-\mathrm{C} 7^{\prime}$ & $1.799(7)$ \\
\hline $\mathrm{P} 1-\mathrm{C} 13$ & $1.832(7)$ & $\mathrm{P} 1^{\prime}-\mathrm{C} 13^{\prime}$ & $1.837(8)$ \\
\hline $\mathrm{P} 2-\mathrm{C} 14$ & $1.805(7)$ & P2' - C14' & $1.818(8)$ \\
\hline $\mathrm{P} 2-\mathrm{C} 15$ & $1.784(9)$ & $\mathrm{P} 2^{\prime}-\mathrm{C} 15^{\prime}$ & $1.805(7)$ \\
\hline $\mathrm{P} 2-\mathrm{C} 21$ & $1.803(7)$ & $\mathrm{P} 2^{\prime}-\mathrm{C} 21^{\prime}$ & $1.794(8)$ \\
\hline $\mathrm{C} 13-\mathrm{C} 14$ & $1.521(9)$ & $\mathrm{C} 13^{\prime}-\mathrm{C} 14^{\prime}$ & $1.533(11)$ \\
\hline $\mathrm{B} 1-\mathrm{P} 1-\mathrm{C} 1$ & $112.8(4)$ & $\mathrm{B} 1^{\prime}-\mathrm{P} 1^{\prime}-\mathrm{C} 1^{\prime}$ & $112.1(4)$ \\
\hline $\mathrm{B} 1-\mathrm{P} 1-\mathrm{C} 7$ & $115.3(4)$ & $\mathrm{B} 1^{\prime}-\mathrm{P} 1^{\prime}-\mathrm{C} 7^{\prime}$ & $113.6(5)$ \\
\hline $\mathrm{B} 1-\mathrm{P} 1-\mathrm{C} 13$ & $110.2(4)$ & $\mathrm{B} 1^{\prime}-\mathrm{P} 1^{\prime}-\mathrm{C} 13^{\prime}$ & $112.0(5)$ \\
\hline $\mathrm{B} 2-\mathrm{P} 2-\mathrm{C} 14$ & $111.8(5)$ & $\mathrm{B} 2^{\prime}-\mathrm{P} 2^{\prime}-\mathrm{C} 14^{\prime}$ & $112.7(5)$ \\
\hline $\mathrm{B} 2-\mathrm{P} 2-\mathrm{C} 15$ & $114.3(5)$ & $\mathrm{B} 2^{\prime}-\mathrm{P} 2^{\prime}-\mathrm{C} 15^{\prime}$ & $115.6(5)$ \\
\hline $\mathrm{B} 2-\mathrm{P} 2-\mathrm{C} 21$ & 113.2(4) & $\mathrm{B} 2^{\prime}-\mathrm{P} 2^{\prime}-\mathrm{C} 21^{\prime}$ & $112.8(5)$ \\
\hline $\mathrm{C} 1-\mathrm{P} 1-\mathrm{C} 7$ & $107.2(3)$ & $\mathrm{C} 1^{\prime}-\mathrm{P} 1^{\prime}-\mathrm{C} 7^{\prime}$ & $107.2(3)$ \\
\hline $\mathrm{C} 1-\mathrm{P} 1-\mathrm{C} 13$ & $104.0(3)$ & $\mathrm{C} 1^{\prime}-\mathrm{P} 1^{\prime}-\mathrm{C} 13^{\prime}$ & $105.3(4)$ \\
\hline $\mathrm{C} 7-\mathrm{P} 1-\mathrm{C} 13$ & $106.5(3)$ & $\mathrm{C} 7^{\prime}-\mathrm{P} 1^{\prime}-\mathrm{C} 13^{\prime}$ & $106.0(4)$ \\
\hline $\mathrm{C} 14-\mathrm{P} 2-\mathrm{C} 15$ & $105.8(5)$ & $\mathrm{C} 14^{\prime}-\mathrm{P} 2^{\prime}-\mathrm{C} 15^{\prime}$ & $105.8(4)$ \\
\hline $\mathrm{C} 14-\mathrm{P} 2-\mathrm{C} 21$ & $106.5(3)$ & $\mathrm{C} 14^{\prime}-\mathrm{P} 2^{\prime}-\mathrm{C} 21^{\prime}$ & $103.7(4)$ \\
\hline $\mathrm{C} 15-\mathrm{P} 2-\mathrm{C} 21$ & $104.6(4)$ & $\mathrm{C} 15^{\prime}-\mathrm{P} 2^{\prime}-\mathrm{C} 21^{\prime}$ & $105.2(3)$ \\
\hline $\mathrm{P} 1-\mathrm{C} 13-\mathrm{C} 14$ & $111.8(5)$ & $\mathrm{P} 1^{\prime}-\mathrm{C} 13^{\prime}-\mathrm{C} 14^{\prime}$ & $110.4(5)$ \\
\hline $\mathrm{P} 2-\mathrm{C} 14-\mathrm{C} 13$ & $111.0(5)$ & P2' - C14' - C13' & $111.7(5)$ \\
\hline
\end{tabular}

Table 4. Structural parameters of pi-ring interaction geometry $\left(\AA \AA^{\circ}\right)$ for the title compound.

\begin{tabular}{lcccc}
\hline \multicolumn{1}{c}{$\mathrm{D}-\mathrm{H} \cdots \mathrm{Cg}$} & $\mathrm{D}-\mathrm{H}$ & $\mathrm{Cg} \cdots \mathrm{H}$ & $\mathrm{D} \cdots \cdots \mathrm{Cg}$ & $\mathrm{D}-\mathrm{H} \cdots \mathrm{Cg}$ \\
\hline $\mathrm{C} 9-\mathrm{H} 9 \cdots \mathrm{Cg} 4$ & 0.93 & 2.81 & $3.685(14)$ & 158 \\
$\mathrm{C} 11^{\prime}-\mathrm{H} 11^{\prime} \cdots \mathrm{Cg} 1 \mathrm{i}$ & 0.93 & 2.79 & $3.634(12)$ & 151 \\
$\mathrm{C} 25^{\prime}-\mathrm{H} 25^{\prime} \cdots \mathrm{Cg} 1{ }^{\prime} \mathrm{ii}$ & 0.93 & 2.91 & $3.662(12)$ & 138 \\
\hline
\end{tabular}

Symmetry codes [i: $\mathrm{x}, \mathrm{y}, 1+\mathrm{z}$ and ii: $1-\mathrm{x}, 1 / 2+\mathrm{y}, 1-\mathrm{z}]$ 


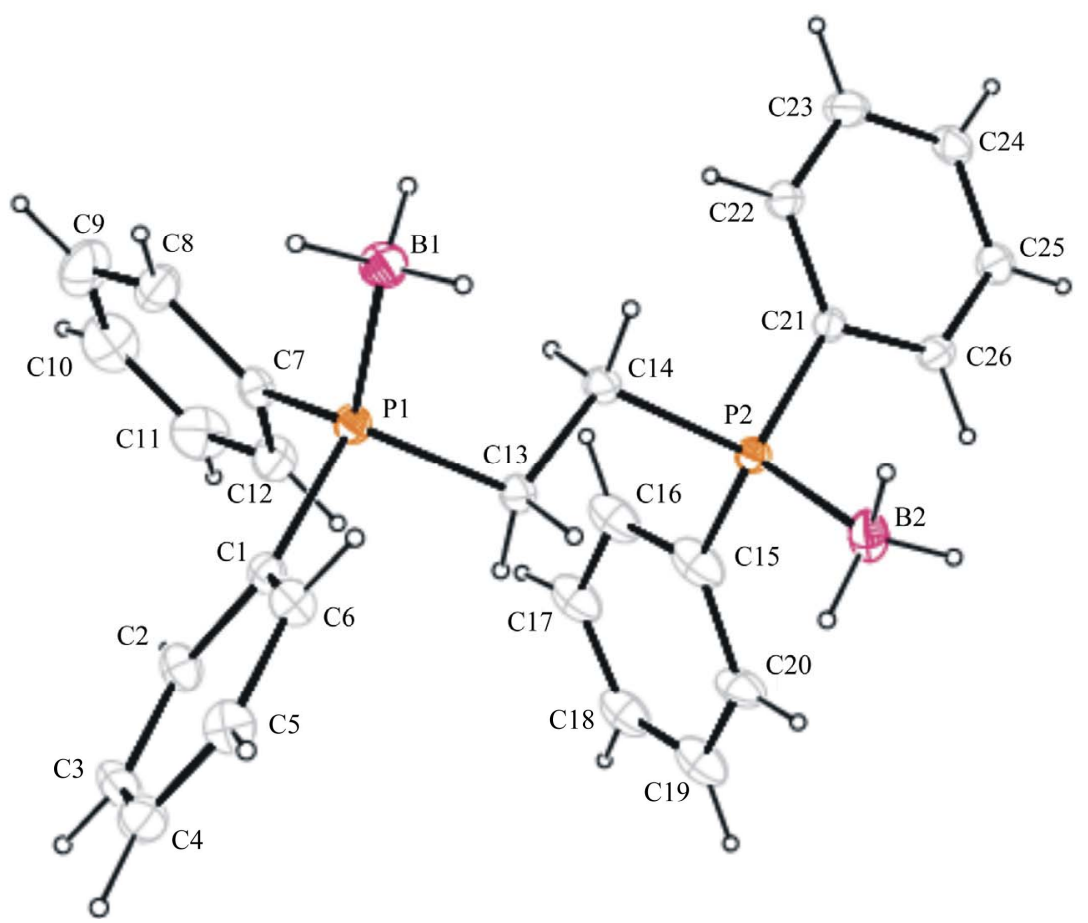

Figure 1. ORTEP drawing for the dppe $\left(\mathrm{BH}_{3}\right)_{2}$ complex with the atomic numbering scheme.

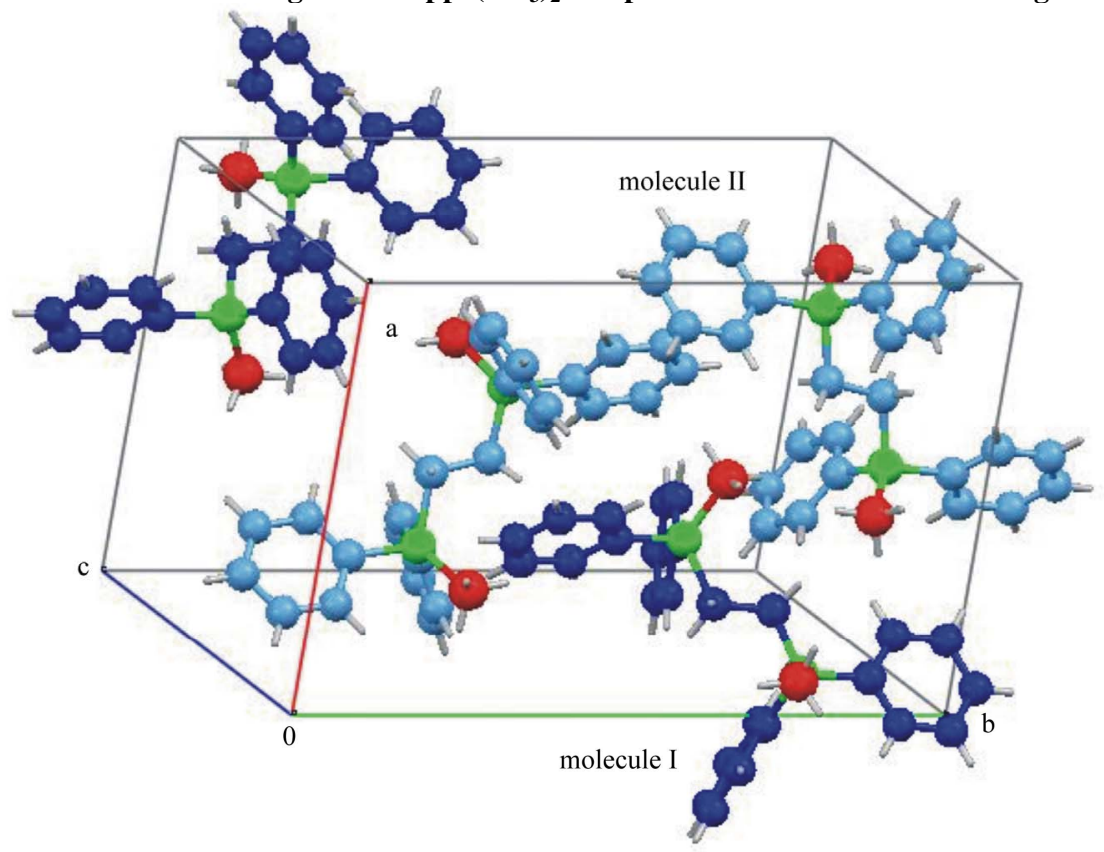

Figure 2. The unit cell of dppe(BH $\left.{ }_{3}\right)_{2}$.

hydrogen evolution, yielding 1,2-bis(diphenylphosphinoborane)ethane, dppe $\left(\mathrm{BH}_{3}\right)_{2}$, which can be isolated by extraction in dichloromethane. Colorless crystals of dppe $\left(\mathrm{BH}_{3}\right)_{2}$ obtained by crystallization from the hexane-dichloromethane solution were used for the single crystal diffraction determination.
In the crystal structure of the title compound, the monoclinic unit cell contains two molecules of $\left[\mathrm{C}_{26} \mathrm{H}_{30} \mathrm{~B}_{2} \mathrm{P}_{2}\right]$ and four molecules per unit cell. All molecular properties of two asymmetric units of the molecule I are similar of the molecule II as given in Table $\mathbf{3}$. 
The average bond angles around phosphorus atoms are $112.9^{\circ}, 113.1^{\circ}, 105.8^{\circ}$, and $105.5^{\circ}$ for B-P-C, B'-P'-C', C-P-C and $\mathrm{C}^{\prime}-\mathrm{P}^{\prime}-\mathrm{C}^{\prime}$, respectively. Study of the interactions between $\mathrm{P}$ atoms and contact atoms in coordination sphere with average distances (P-B: $1.876 \AA$ for the molecule I, $1.905 \AA$ for II and P-C $1.804 \AA$ for I, 1.809 $\AA$ for II) reveals that the P atoms are surrounded by four atoms (one boron and three carbon atoms) in nearly ideal tetrahedral geometry.

Both molecules in an asymmetric unit have a similar three-dimensional conformation. Dihedral angles between the least square planes of phenyl rings in coordination sphere of $\mathrm{P}$ atoms are $\mathrm{Cg} 1-\mathrm{Cg} 2=76.4(3) \AA \mathrm{Ag} 3-$ $\mathrm{Cg} 4=88.2(3) \AA$ for molecule $\mathbf{I}$ and $\mathrm{Cg} 5-\mathrm{Cg} 6=71.2(3)$ $\AA, \mathrm{Cg} 7-\mathrm{Cg} 8=71.5(3) \AA$ for molecule II. Figure 2 shows the unit cell of dppe $\left(\mathrm{BH}_{3}\right)_{2}$.

There is no classic hydrogen bond in the structure but the compound includes several pi-ring interactions between two asymmetric moieties. Rings are composed of atoms $\mathrm{Cg} 1=\mathrm{C} 1 / \mathrm{C} 6, \mathrm{Cg} 2=\mathrm{C} 7 / \mathrm{C} 12, \mathrm{Cg} 3=\mathrm{C} 15 / \mathrm{C} 20$, $\mathrm{Cg} 4=\mathrm{C} 21 / \mathrm{C} 26, \mathrm{Cg} 1^{\prime}=\mathrm{C}^{\prime} / \mathrm{C} 6{ }^{\prime}, \mathrm{Cg} 2^{\prime}=\mathrm{C}^{\prime} / \mathrm{C} 12^{\prime}, \mathrm{Cg} 3^{\prime}=$ $\mathrm{C} 15^{\prime} / \mathrm{C} 20^{\prime}, \mathrm{Cg} 4^{\prime}=\mathrm{C} 21^{\prime} / \mathrm{C} 26^{\prime}$. Details of the pi-ring interaction geometry are given in Table 4.

The solution NMR data of 1,2-bis(diphenylphosphinoborane)ethane, dppe $\left(\mathrm{BH}_{3}\right)_{2}$, are also in good agreement with the single crystal structure. It is noteworthy that the ${ }^{1} \mathrm{H}$ NMR spectrum gives two doublets at 2.15 and $2.38 \mathrm{ppm}$ for the prochiral methylene groups [28] while the ${ }^{13} \mathrm{C}$ NMR spectrum exhibits only one signal at $22.93 \mathrm{ppm}$ for the methylene carbons. Moreover, two separated multiplets at 7.54 and 7.61 ppm are observed for ortho-hydrogens of phenyl rings and similar to hydrogens of methylene groups, ortho-hydrogens of phenyl rings are not identical due to their different positions with respect to borane moieties. ${ }^{31} \mathrm{P}$ NMR spectrum shows a peak at $-12.5 \mathrm{ppm}$ which is about $10 \mathrm{ppm}$ more shielded than corresponding peak of meso-[ $\left.\mathrm{HP}\left(\mathrm{BH}_{3}\right)(\mathrm{Ph}) \mathrm{CH}_{2}\right]_{2}$ complex [4], indicating that dppe $\left(\mathrm{BH}_{3}\right)_{2}$ complex containing more phenyl rings has more electron-rich phosphorus atoms. However, ${ }^{11} \mathrm{~B}$ NMR gives a peak at $-40.06 \mathrm{ppm}$ for borane groups comparable to the value of -41.6 ppm reported for meso-[HP( $\left.\left(\mathrm{BH}_{3}\right)(\mathrm{Ph}) \mathrm{CH}_{2}\right]_{2}$ complex [4]. MS does not show the molecular ion peak expected at $\mathrm{m} / \mathrm{z}=425$. Instead, it shows peaks at $\mathrm{m} / \mathrm{z}=$ 429 or 431 due to oxidation of dppe $\left(\mathrm{BH}_{3}\right)_{2}$ during the sampling/ionization whereby $\mathrm{BH}_{3}$ groups are replaced by the oxo groups.

\section{Conclusions}

In conclusion, sodium borohydride is a facile $\mathrm{BH}_{3}$ source in the synthesis of phosphanylborohydride compounds such as 1,2-bis(diphenylphosphinoborane)ethane, dppe
$\left(\mathrm{BH}_{3}\right)_{2}$, in high yield. Sodium borohydride and metaborate are easily separated by extraction with dichloromethane, providing an easy separation for the preparation of phosphanylborohydrides with high purity. The adduct dppe $\left(\mathrm{BH}_{3}\right)_{2}$ crystallizes in monoclinic system with space group $P 2_{1}$ and two asymmetric units containing nearly ideal tetrahedral phosphorus atoms.

\section{Acknowledgements}

Partial support of this work by the Turkish Academy of Sciences and the Scientific and Technological Research Council of Turkey (TUBITAK, Project No.: 105M357) is gratefully acknowledged. L.T. Yildirim thanks Hacettepe University Scientific Research Unit (grant No. 04 A602004) for financial support. MM thanks TUBITAK for awarding a PhD fellowship. We thank Mr. Bunyamin Cosut from Gebze Institute of Technology for performing mass analysis.

\section{REFERENCES}

[1] M. Masjedi, T. Demiralp and S. Ozkar, "Testing Catalytic Activity of Ruthenium (III) Acetylacetonate in the Presence of Trialkylphosphite or Trialkylphosphine in Hydrogen Generation from the Hydrolysis of Sodium Borohydride," Journal of Molecular Catalysis A: Chemical, Vol. 310, No. 1-2, 2009, pp. 59-63. doi:10.1016/j.molcata.2009.05.022

[2] K. C. Nainan and G. E. Ryschkewitsch, "A New Synthesis of AMINE- and Phosphine-Boranes," Inorganic Chemistry, Vol. 8, No. 12, 1969, pp. 2671-2674. doi: $10.1021 /$ ic50082a027

[3] O. Stephan, N. Riegel and S. Juge, "Polypyrrole Bearing Diphosphine Borane Groups: A New Way to Prepare Polymer-Supported Phosphine Ligands. Application to Palladium Catalysed Reactions," Journal of Electroanalytical Chemistry, Vol. 421, No. 1-2, 1997, pp. 5-8. doi:10.1016/S0022-0728(96)01027-3

[4] F. Dornhaus, M. Bolte, H-W. Lerner and M. Wagner, "The First Bidentate Phosphanylborohydrides: Synthesis, Structure and Reactivity Towards [CpFe(CO)2I]," Journal of Organometallic Chemistry, Vol. 692, No. 14, 2007, pp. 2949-2955. doi:10.1016/j.jorganchem.2007.03.006

[5] R. A. Geanangel, "The Reaction of Amine and Phosphine Oxides with Diborane," Journal of Inorganic and $\mathrm{Nu}$ clear Chemistry, Vol. 36, No. 6, 1974, pp. 1397-1398. doi:10.1016/0022-1902(74)80085-0

[6] G. Jugie, J. P. Laussac and J. P. Laurent, "Addition Compounds of Trialkylphosphines (R3P) with Bromoboranes or Bromochloroboranes," Bulletin de la Societe Chimique de France, Vol. 7, 1970, pp. 2542-2544.

[7] S. Juge, M. Stephan, J. A. Laffitte and J. P. Genet, "Efficient Asymmetric Synthesis of Optically Pure Tertiary Mono and Diphosphine Ligands," Tetrahedron Letters, 
Vol. 31, No. 44, 1990, pp. 6357-6360.

doi:10.1016/S0040-4039(00)97063-1

[8] S. Juge, M. Stephan, R. Merdes, J. P. Genet and S. HalutDesportes, "Stereochemistry of the P-C Bond Formation in an Oxazaphospholidine Borane Complex," ChemInform, 1993, pp. 531-533.

[9] B. E. Kaloun, R. Merdes, J. P. Genet, J. Uziel and S. Juge, "Asymmetric Synthesis of (S,S)-(+)-1,1'-bis-(Methylphenyl-Phosphino) Ferrocene," Journal of Organometallic Chemistry, Vol. 529, No. 1-2, 1997, pp. 455-463. doi:10.1016/S0022-328X(96)06690-9

[10] H. Schmidbaur, M. Sigl and A. Schier, "Synthesis and Structure of Cyclic Phosphine-Boranes," Journal of Organometallic Chemistry, Vol. 529, No. 1-2, 1997, pp. 323-327. doi:10.1016/S0022-328X(96)06616-8

[11] R. Nunez, C. Vinas, F. Teixidor, R. Sillanpaa and R. Kivekas, "Phosphine-Boranes Incorporating the Carborane Cluster," Journal of Organometallic Chemistry, Vol. 657, No. 1-2, 2002, pp. 224-231. doi:10.1016/S0022-328X(02)01326-8

[12] J. A. Baban and B. P. Roberts, "Homolytic Reactions of Ligated Boranes. Part 3. Electron Spin Resonance Studies of Radicals Derived from Dialkyl-Amine Boranes," Journal of the Chemical Society, Perkin Transactions 2, Vol. 10, 1986, pp. 1607-1611. doi:10.1039/p29860001607

[13] H. Schmidbaur, G. Mueller and G. Blaschke, "Darstellung und Eigenschaften Einfacher und Stark Sterisch Gehinderter Phosphanalkylenborane," Chemische Berichte, Vol. 113, No. 4, 1980, pp. 1480-1486. doi:10.1002/cber.19801130427

[14] F. Dornhaus, M. Bolte, H.-W. Lerner and M. Wagner, "Phosphanylborohydrides: First Assessment of the Relative Lewis Basicities of $\left[\mathrm{BH}_{3} \mathrm{PPh}_{2}\right]^{-}, \mathrm{CH}_{3} \mathrm{PPh}_{2}$ and $\mathrm{HPPh}_{2}$," European Journal of Inorganic Chemistry, Vol. 2006, No. 9, 2006, pp. 1777-1785. doi:10.1002/ejic.200501126

[15] F. Dornhaus, M. Bolte, H-W. Lerner and M. Wagner, "A Comparative Study of Chalcogenated Phosphanylborohydrides $\left[\mathrm{EPR}_{2} \mathrm{BH}_{3}\right]^{-}(\mathrm{R}=\mathrm{Ph}, \mathrm{tBu})$ and Triorganophosphane Chalcogenides $\mathrm{EPPh}_{2} \mathrm{CH}_{3}(\mathrm{E}=\mathrm{O}, \mathrm{S}, \mathrm{Se}, \mathrm{Te})$, European Journal of Inorganic Chemistry, 2006, pp. 5138-5147. doi:10.1002/ejic.200600753

[16] S. Sayalero and M. A. Pericas, "Work-up-Free Deprotection of Borane Complexes of Phosphines, Phosphites and Phosphinites with Polymer-Supported Amines," Synlett, Vol. 16, 2006, pp. 2585-2588.
[17] W. Angerer, W. S. Scheldrick and W. Malisch, "Ubergangsmetallsubstituierte Phosphane, Arsane und Stibane, XLVI, Einige Reaktionen des Ferrio-Phosphanes $\mathrm{C}_{5} \mathrm{Me}_{5}(\mathrm{CO})_{2}$ $\mathrm{Fe}-\mathrm{PPh}_{2}$ und Molekulstruktur Seines Boran-Addukts," Chemische Berichte, Vol. 118, 1985, pp. 1261-1266. doi:10.1002/cber.19851180339

[18] D. A. Hoic, W. M. Davis and G. C. Fu, "Diphenylphosphidoboratabenzene: An Anionic Analogue of Triphenylphosphine," Journal of the American Chemical Society, Vol. 118, 1996, pp. 8176-8177. doi: $10.1021 / \mathrm{ja} 9615740$

[19] A.-C. Gaumont, M. B. Hursthouse, S. J. Coles and J. M. Brown, "Isolation of the Reactive Intermediate in Palladium-Catalysed Coupling of Secondary Phosphine-Boranes with Aryl Halides," Chemical Communications, Vol. 1, 1999, pp. 63-64. doi: $10.1039 / \mathrm{a} 807830 \mathrm{k}$

[20] H. Dorn, C. A. Jaska, R. A. Singh, A. J. Lough and I. Manners, "Synthesis and Novel Reactivity of Platinum Phosphine-Borane Complexes trans- $\left[\mathrm{PtH}\left(\mathrm{PPhR} . \mathrm{BH}_{3}\right)\right.$ $\left.\left(\mathrm{PEt}_{3}\right)_{2}\right](\mathrm{R}=\mathrm{H}, \mathrm{Ph})$, ' Chemical Communications, Vol. 12, 2000, pp. 1041-1042. doi:10.1039/b002615h

[21] G. Muller and J. Brand, "Mono(Borane)Phosphides as Ligands to Lithium and Aluminum," Organometallics, Vol. 22, 2003, pp. 1463-1467. doi:10.1021/om0209430

[22] C. A. Jaska, A. J. Lough and I. Manners, "Linear Hybrid Aminoborane/Phosphinoborane Chains: Synthesis, Proton-Hydrid Interactions and Thermolysis Behavior," Inorganic Chemistry, Vol. 43, No. 3, 2004, pp. 1090-1099.

[23] Enraf-Nonius, "CAD-4 EXPRESS,” Enraf-Nonius, Delft, 1994.

[24] K. Harms and S. Wocadlo, "XCAD4," University of Marburg, Marburg, 1995.

[25] G. M. Sheldrick, "A Short History of SHELX," Acta Crystallographica, Vol. A64, 2008, pp. 112-122.

[26] L. J. Farrugia, "XRDIFF: Simulation of X-Ray Diffraction Patterns," Journal of Applied Crystallography, Vol. 30, No. 5-1, 1997, pp. 565-566.

[27] A. L. Spek, "Single-Crystal Structure Validation with the Program PLATON," Journal of Applied Crystallography, Vol. 36, No. 1, 2003, pp. 7-13. doi:10.1107/S0021889802022112

[28] R. K. Harris, "Comments on N. M. R. Spectra of the $\mathrm{X}_{\mathrm{n}} \mathrm{AA}^{\prime} \mathrm{X}_{\mathrm{n}}$ ' Type," Canadian Journal of Chemistry, Vol. 42, No. 10, 1964, pp. 2275-2281. doi:10.1139/v64-334 